Damayanti, M., Ruhanen, L. and Scott, N. (2017) Coopetitive behaviors in an informal tourism economy Annals of Tourism Research, 65, 25-35.

\title{
COOPETITIVE BEHAVIOURS IN AN INFORMAL TOURISM ECONOMY
}

\begin{abstract}
In the business literature, coopetition is defined as simultaneous cooperative and competitive activities among actors. In the informal economy, norms and trust take the place of formal contracts among actors and may allow these actors to move from engaging in competition to cooperation easily suggesting that patterns of coopetition in this context might be different to that in the formal economy. This research explores coopetition among informal tourism economy actors using the Institutional Analysis and Development Framework and the concept of shared resources. The results of qualitative case studies of pedicab drivers and street vendors in Yogyakarta indicate that simultaneous coopetition occurs when the actors share multiple resources while sequential coopetition occurs in the context of a single shared resource.
\end{abstract}

Keywords: coopetition; Institutional Analysis and Development (IAD) Framework; informal economy.

\subsection{INTRODUCTION}

Since the 1970s, the term informal economy has been used to describe people, usually in less developed and developing countries, who are engaged in work that is not contracted employment or self-employment (Todaro \& Smith, 2012). These workers are generally poor, unskilled and disadvantaged and work in the informal sector for a variety of reasons including an inability to access formal employment markets. Their work is often casual and the wages generally lower than those in similar positions in the formal sector (Hart, 2006). Yet, in spite of the conditions, for the poor or disadvantaged, such employment may be the only opportunity for survival (Meagher, 2005; Rakodi \& Lloyd-Jones, 2002). Informal activities are often found in tourist spaces, and can include street vendors who cluster around tourist coaches and try to sell their goods, and beach boys who try to befriend tourists as guides (Bah \& Goodwin, 2003). Street 
food vendors, market holders and local transport providers may also work within the informal economy in some countries. In some destinations, informal economic activities such as market vendors may become iconic attractions (Kermath \& Thomas, 1992) and a key part of the destination's tourism product.

The tourism-related income from informal activities can benefit a community significantly (Cukier, 2002; Ketchen, Ireland \& Webb, 2014; Slocum, Backman \& Robinson, 2011). However informal economy workers face challenges including government regulations that constrain their access to resources, such as capital and retail space (Bhowmik, 2005; Donovan, 2008; ILO, 2003; Lyons \& Snoxell, 2005b), and the ease with which new competitors can set themselves up due to low barriers to entry (Bosch \& Esteban-Pretel, 2012; Chen, 2006; Sethuraman, 1976). Informal economy participants may redress these challenges by occupying urban public spaces such as squares and streets near tourist attractions (Bhowmik, 2005; Yeo \& Heng, 2014).

Previous studies of the informal economy illustrate that actors adopt different types of strategies in order to survive in contested urban areas. Street vendors in Ankara, Cali, Mexico City, and African cities have been found to compete for limited trading places in public spaces (Bromley, 1978; Brown, Lyons \& Dankoco, 2010; Peña, 1999; Varcin, 2000). Here "business is war” (Brandenburger \& Nalebuff, 1996, p. 3), and actors try to defeat their competitors (Dagnino, 2009). An alternative view is that actors need to use cooperative strategies to survive. The characteristics of informal economies, such as limited capital availability and labour intensity, may also lead actors to cooperate. This cooperation may be through exchange of favours or money (Lyons \& Snoxell, 2005a) or establishment of an association or union to provide collective bargaining (Fajana, 2008; Peña, 1999). Both competitive and cooperative strategies can provide advantages in dealing with an uncertain future.

Neoclassical economic scholars argue that such competitive and cooperative strategies are theoretically independent and opposite (Gomes-Casseres, 1996), while behavioural and game theory scholars argue that they may be interdependent (Chen, 2008; Walley, 2007). A combination of these strategies is termed as 'coopetition', which, in the context of the formal economy, is defined as a simultaneous relationship among actors that illustrates both cooperative and competitive behaviours (Bengtsson \& Kock, 2000, 2014). For instance, coopetition may occur in a high-tech product's value chain where companies compete in developing new technology but cooperate in the marketing of their products (Bonel \& Rocco, 2007; Gnyawali \& 
Park, 2011). Similarly networks of tourism business operators compete for customers but cooperate through marketing to attract visitors to the destination (Belleflamme \& Neysen, 2009; Wang \& Krakover, 2008).

Studies of coopetition in the formal economy context also illustrate the complexity of the concept due to the different process and outcomes of competition and conflict, or cooperation and harmony that challenge actors to find the right balance. In many contexts this is done through establishing institutional structures or arrangements (Bengtsson \& Kock, 2000; Teece, 1992) or 'rules of the game' (Ostrom, 2005b, 2011). For instance, a formal contract is an institutional arrangement that reduces uncertainty in cooperation by using legal means to specify agreed outcomes and sanctions for non-performance (Eriksson, 2008). However, given that the informal economy actors may have a questionable legal status, arranging formal contracts among competing actors is difficult. Thus, informal institutions are based on norms and trust that represent the rules of the game among actors. Importantly, a lack of formal contracts may allow these actors to move from engaging in competition to cooperation or vice versa quickly. Therefore, patterns of coopetition in the context of informal economy might be different to that in the formal economy.

The aim of this paper is to explore patterns of coopetition among actors in the informal economy. The existence of competitive and cooperative behaviours in an informal tourism economy has not previously been examined and extends the concept of coopetition that has developed in the formal economy context. Moreover, such tourism-related employment in the informal economy is under-researched and perceived as hidden, marginalized, and silent (Briassoulis, 1999, 2001; Torfing, 2006). The paper explores the pattern of coopetition among informal economy actors using Ostrom’s Institutional Analysis and Development (IAD) Framework (Ostrom, 2005b, 2011). At the core of the IAD framework is the action situation that is defined as social space where/when two or more actors interact and exchange resources or compete/fight in gaining resources (Ostrom, 2005b, 2011). Hence, the IAD framework is applicable to examine coopetition behaviours among actors. Furthermore, the complexity of coopetition can be explored comprehensively, particularly by linking coopetition with the shared resources among actors, applied rules in use/institutions, and attributes of the actors.

A qualitative case study was employed to examine pedicab drivers and street vendors in the informal economy in Yogyakarta, Indonesia. Yogyakarta was chosen as the context for this 
research because this city is one of the main tourist destinations in Indonesia, and a significant informal tourism economy exists in this destination (Dahles \& Bras, 1999; Hampton, 2003; Timothy \& Wall, 1997; van Gemert, van Genugten \& Dahles, 1999). Data included semistructured interviews, naturalistic observation, as well as document analysis.

\subsection{COOPETITION}

The economic concept of coopetition originated in game theory, recognizing competition with others as a zero-sum game and cooperation as a positive-sum game that emphasizes mutual benefits (Brandenburger \& Nalebuff, 1995; Padula \& Dagnino, 2007; Palmer, 2000). Coopetition is a variable-positive-sum game that presents mutual gain, but does not necessarily bestow fair benefits on partners (Dagnino \& Padula, 2002). Coopetition is a complex strategy as the partners have to cooperate without ignoring their own interest, and compete without eliminating their competitors (Brandenburger \& Nalebuff, 1996).

Previous studies have identified patterns of coopetition based on the types of relationships that exist among actors. For example, horizontal relationships are commonly found in the manufacturing industry and involve simultaneous direct competitive and cooperative interactions among members of a product(s) value chain (Bengtsson \& Kock, 2000). An example of cooperation is that of Sony and Samsung in developing television technology while concurrently competing for customers (Gnyawali \& Park, 2011). Vertical relationships emphasize the value creation network of various actors including competitors, complementors, buyers or sellers (Brandenburger \& Nalebuff, 1996; Walley, 2007) as is also the case for destination marketing (Belleflamme \& Neysen, 2009; Kylänen \& Rusko, 2010; von Friedrichs Grängsjö, 2003; Wang \& Krakover, 2008). Here accommodation, attractions and transportation businesses, as well as Destination Marketing Organizations (DMOs), work together in the promotion of a destination yet still compete to attract visitors. In this type of relationship, competition is indirect and through buyers (Bengtsson \& Kock, 2000) or other actors such as the DMO. Vertical relationships may also occur within an organization where control and coordination systems determine the cooperation and competition among business units (Padula \& Dagnino, 2007). In the informal economy, horizontal coopetition relationships among actors occur more often than vertical ones. Informal economy actors are in direct everyday competition to access public space 
while also cooperating to save money (Bhowmik, 2005). Informal actors may also work with formal economy actors in vertical relationships as illustrated in the cooperation that took place between the beach resorts and beach hawkers in Phuket, Thailand after the 2004 tsunami (Smith \& Henderson, 2008).

Coopetition has also been studied based on the relationships between the actors involved in competitive and cooperative activities. Coopetition is present when cooperation and competition simultaneously occur among two or more actors (Bengtsson \& Kock, 2000, 2014; Brandenburger \& Nalebuff, 1996) although there are different interpretations of 'simultaneous'. Brandenburger and Nalebuff (1996) consider that two or more actors (can be producers of different products) cooperate to create the new value of the product(s), and compete with other actors in sharing the value of the product(s). Thus cooperation and competition occurs simultaneously but between different groups of actors. Other scholars (Bengtsson \& Kock, 2000; Galvagno \& Garraffo, 2010; Gnyawali \& Park, 2011; Luo, 2004; Walley, 2007) consider that coopetition involves the same actors who compete and cooperate at the same time.

This discussion suggests that coopetition must be analysed in terms of the cooperative and collaborative activities undertaken, the actors involved and their sequence in time. Competitive activities may be defined as self-interested behaviour involving rivalry for the possession of a certain object or achievement that cannot be shared with others (Burke, Genn-Bash \& Haines, 1991; Enz, 2010), where attainment of the object indicates the success of a competitor. On the other hand, cooperation emphasizes interdependencies among actors to gain competitive advantage (Della Corte \& Aria, 2016; Ma, 2004; Wilkinson \& Young, 2002) where the value of success is based on mutual benefit among the actors (Dagnino, 2009; Nielsen, 1988). This different nature of competition and cooperation is a reason why coopetition is a complex situation as the actors need to gain mutual benefit without foregoing their individual benefit.

The definition of coopetition indicates that the sequence of coopetition activities is simultaneous where actors cooperate and compete at the same time. However, the actual timing or temporal sequence of coopetition is rarely discussed in the literature. In the study of coopetition between Sony and Samsung mentioned above, Gnyawali and Park (2011) examined how these companies cooperated and competed over seven years. This may be a reasonable interpretation of "simultaneous" in this case because developing technology is time consuming and longer term. However other authors such as Galvagno and Garraffo (2010) criticize the 
unclear time perspective in the coopetition literature and highlight different configurations of competition and cooperation (see Fig. 1). At some times ( $t_{0}$ or $\left.t_{1}\right)$, actors interact through pure cooperation or competition, while at $\mathrm{t}_{2}$ they operate in a mixed mode simultaneously. Over the whole period ( $t_{0}$ to $t_{n}$ ), we may identify two types of coopetition, one sequential and the other simultaneous, although both have been termed coopetition in the literature.

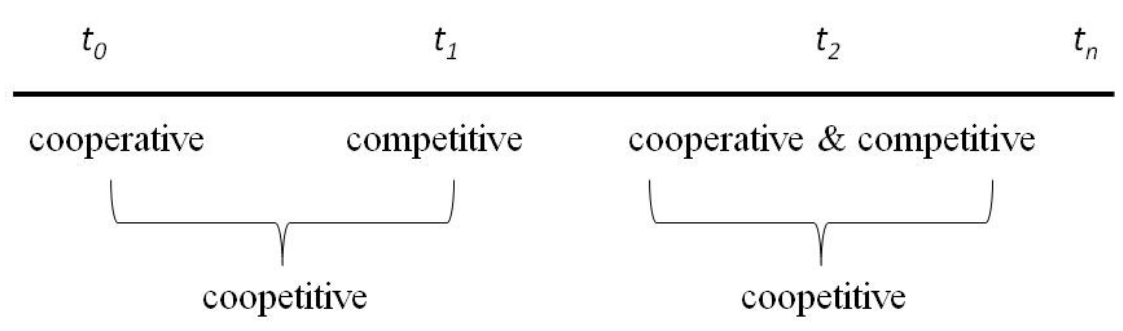

Fig. 1. The effect of temporal ordering. Source: Galvagno and Garraffo (2010, p. 45)

The informal economy context challenges the models of actors, activities, and their temporal ordering found in the formal economy literature. In the informal economy actors' decisions to compete or cooperate may not be purely based on their individual benefit consideration, as these competing actors may be also involved in personal relationships or hierarchical organisations such as unions. Additionally, actor interactions on one day may change in subsequent interactions over the following days, a situation not currently discussed in the literature of coopetition. To examine the situation in more detail, the Institutional Analysis and Development (IAD) Framework is adopted to better explain how the characteristics of the actors and other factors influence their decisions to cooperate or compete.

\subsubsection{Institutional Analysis and Development (IAD) Framework}

The IAD Framework was developed to understand how institutions operate (Coleman \& Steed, 2009; McGinnis, 2011). It is an alternative approach to institutional studies that have been dominated by market-focused economic theory and political studies of hierarchies (Ostrom, 2005a) and instead provides an interdisciplinary framework examining how institutions affect individual behaviour (Ostrom, 2009). The core of the IAD Framework is an action situation that 
is influenced by external variables (Ostrom, 2010), interactions between actors, and the actors concerns about a particular situation. The components of the framework are:

Contextual factors/external variables consisting of biophysical conditions that refer to the nature of goods or shared resources among the actors, attributes of community that include internal homogeneity and heterogeneity of the actors, the knowledge and social capital of the actors who participate in each action situation, and the rules in use. Rules in use are common understandings among the actors that define what actions, behaviours, or outcomes are required, prohibited, or permitted. These 'rules in use' might include formal regulation and informal institutions within the community (Ostrom, 2005b; 2009, 2010, 2011).

Action situations are at the core of the IAD Framework and represent the social space where two or more individual actors interact, exchange resources (cooperate), and/or fight (compete) in producing outcomes. The results of action situations form a pattern of interactions among actors and outcomes (McGinnis, 2011; Ostrom, 2005b; 2009, 2010, 2011).

Outcomes are the potential results of each action situation for the actors (internal valuation on the rewards/benefits and costs), as well as the shared resources (focuses on the sustainability of shared resources, particularly the common pool resources) (Clement, 2010; Mishra \& Kumar, 2007; Ostrom, 2005b; 2009, 2010, 2011).

Evaluative criteria are the tools that the institutional analyst uses to evaluate the best alternative based on the outcomes and process of an action situation, such as economic efficiency, equity in terms of fiscal equivalence and redistribution of outcomes, accountability, and adaptability in terms of ability to respond environmental changes (Ostrom, 2005b; 2009, 2010, 2011).

The concept of shared resources is derived from two characteristics of goods, that is, subtractability of use (jointness of use or consumption) and difficulty of excluding potential beneficiaries. Based on these two characteristics, goods can be classified into private goods, public goods, common-pool resources, and toll/club goods (Ostrom, 2005b) as shown in Table 1.

\section{Table 1}

Four basic types of goods.

\begin{tabular}{llll}
\hline & \multicolumn{2}{c}{ Sub-tractability of use } \\
\cline { 2 - 3 } $\begin{array}{l}\text { Difficulty of excluding } \\
\text { potential beneficiaries }\end{array}$ & Low & High \\
\cline { 2 - 3 } & Low & Toll (club) goods & Private goods
\end{tabular}


$\begin{array}{lll}\text { High Public goods Common-pool resources } & \end{array}$

Source: Adapted from Ostrom (2005b, p. 24)

'Private goods' are both subtractive goods and high rival in consumption. These goods are commonly provided by the market, and the actors acquire property rights for the goods by paying the cost of consumption (Adams \& McCormick, 1987). 'Public goods’ refer to non-subtractive goods that all users can gain benefits from. In the case of 'common pool resources', users cannot be excluded from accessing the resources, but the consumption of this type of goods by one user can influence other users’ opportunities to gain access to the common pool resources (Briassoulis, 2002; Ostrom, 2005b). Lastly, ‘toll/club goods’ refers to non-rivalrous but small scale goods that members of the club can gain benefit from while excluding non-members from their consumption. Membership fees or toll payments are the determinant factor necessary to benefit from club goods. This payment is referred to as the exclusion cost for the club goods, and may consist of a single membership fee (coarse exclusion) or a single entry fee (fine exclusion) (Sandler \& Tschirhart, 1997).

In order to explore the pattern of coopetitive behaviour among actors in the informal economy, two different concepts have been reviewed: coopetition and the IAD Framework. Fig. 2 illustrates the linkages between these concepts. Attributes of the actors (in the informal economy) are discussed in both the IAD Framework and the coopetition literatures. In conjunction with shared resources and rules in use from the IAD Framework, as well as time from the coopetition concept, these factors influence action situations among actors. In this research these action situations are explored both as cooperation and competition activities. Furthermore, the sequence of these action situations illustrates the pattern of coopetition among actors in the informal economy. 

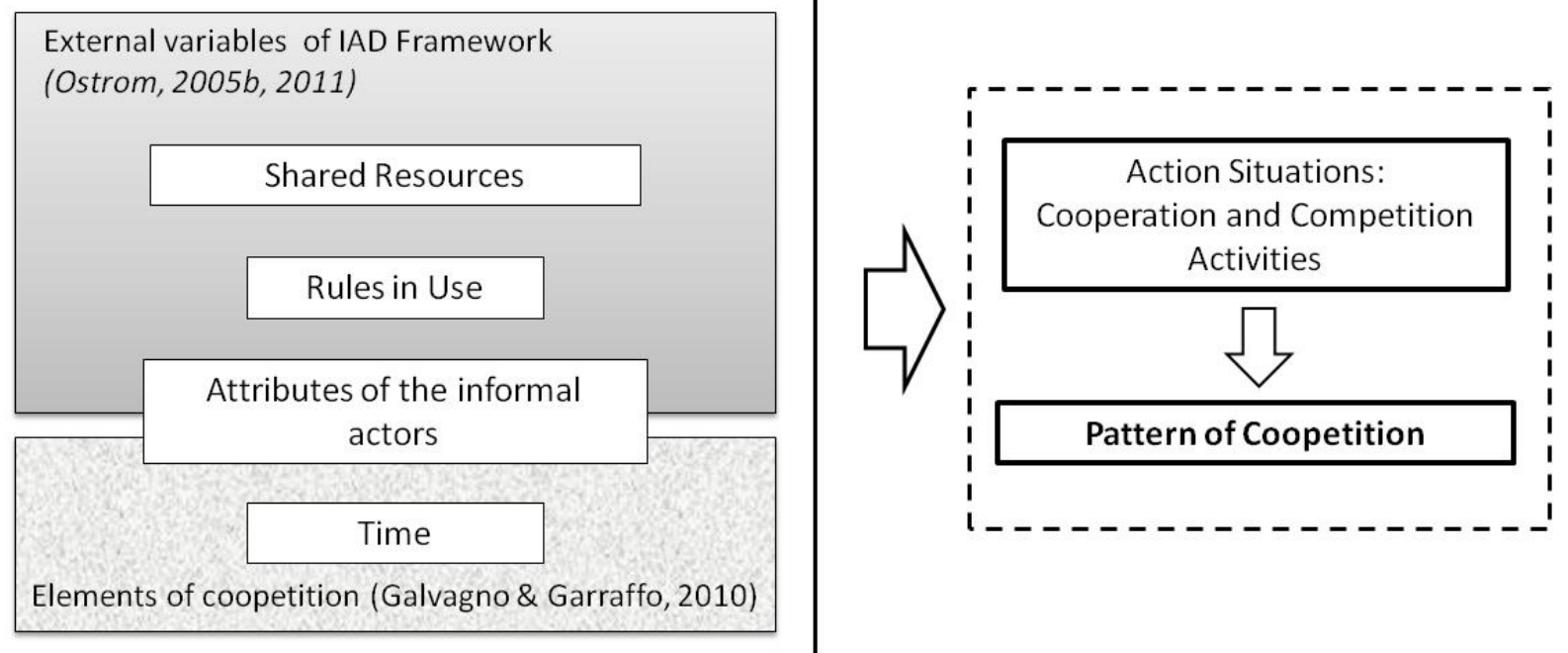

Fig. 2. The concept of coopetition with IAD Framework in defining the pattern of coopetition

\subsection{METHODOLOGY}

This study adopts an exploratory case study in order to explore the coopetitive behaviours of the informal tourism economy (Eisenhardt, 1989; Yin, 2009), with two case studies on the pedicab drivers and street vendors in Yogyakarta, Indonesia. The research design used applied semi-structured interviews as well as naturalistic observations of the daily work activities of the actors. Additionally, legal documents (local government acts and statistical reports) as well as online reports and news items relating to the pedicab drivers and street vendors were analysed.

The data were collected in January-March 2012 using a snowball sampling strategy due to the difficulties in accessing a representative sample of actors from the populations of the informal tourism economy under study (Biernacki \& Waldorf, 1981; Heckathorn, 2002). In order to explore the coopetition behaviours in each level (individual, group, and inter-group), the participants were required to be union members. Based on the consideration that each union will represent different characteristics, this research selected four pedicab driver unions located in locations surrounding Kraton, and four street vendor unions selling two types of goods (food and non-food) in four different locations. In total, 47 informal economy actors were interviewed, consisting of 26 pedicab drivers (5-8 participants in each union) and 21 street vendors (5-6 participants in each union). Here, the number of participants in each union was determined based on the saturation of information for each case (Marshall, 1996; Uriely \& Belhassen, 2006). 
Interviews were focused around two main areas of questioning: the types of cooperation and/or competition activities that were undertaken and under what condition(s) were cooperation and/or competition performed. Interviews generally ranged from 40 to 60 minutes. All interviews were recorded and notes were taken. The transcription is in Bahasa (Indonesian official language) in order to maintain all the information from participants, particularly the latent content that might be embedded within the whole body of transcription. These transcriptions were then used as raw data for content analysis.

Content analysis of transcription of the data gathered from interviews as well as written notes from observations and documents was undertaken using latent coding. Software NVivo 9.2 was used to assist in managing raw data including coding and creating memo in English. This software allows searching, exploring, and linking patterns of data and ideas (Bazeley \& Richards, 2000; Richards, 1999).

\subsubsection{The Pedicab Drivers}

The pedicab or the cycle rickshaw is a traditional transportation mode used throughout Asia, including in Yogyakarta. During the Yogyakarta tourism boom in the 1990s, pedicab drivers in the region responded to increased numbers of tourists by transforming and developing their product through a range of innovative practices. For instance, the traditional pedicabs were modified with more comfortable seats and painted with brighter colours for distinctiveness, and re-named to 'becak wisata', meaning a pedicab for tourism activities (Damayanti, Ruhanen, \& Scott, 2011). In order to organize their activities, the pedicab drivers in a particular location/colocated form a union. In this study, we explore four unions of pedicab drivers surrounding Kraton, i.e. Big Mosque, Dronjonjang Trikora, Keben, and Educational Park.

\subsubsection{The Street Vendors}

Malioboro Street is a well-known shopping area attracting tourists in Yogyakarta lined with street vendors who sell various goods and services such as foods, art, and souvenirs (Putri, 2009; Timothy \& Wall, 1997). The street vendors in Malioboro are generally family operated businesses (Timothy \& Wall, 1997). Recent studies identified more than 2,400 street vendors in 
Malioboro Street (Widiyanto, 2013) although not all of these vendors work at the same time (day/night shifts). For instance, the lesehan (sit-on-the-ground, temporary cafes that sell traditional food) provide their goods only at night when the permanent shops are closed.

Until the mid-80s street vendors were illegal, but later were issued licences by the local authority (Putri, 2009; Timothy \& Wall, 1997). With this license the street vendor has a certain location for their stall, as well as the right to operate at certain times. Further, the street vendors formed various vendors' associations and unions to coordinate their activities, represent them in dealings with the municipal government, and provide savings and loans for the members (Timothy \& Wall, 1997). The unions of street vendors usually represent vendors with similar products within a particular location/ co-located. In this study, we explore four unions of street vendors in Malioboro Street, i.e. non food vendors (Tridarma and Pemalni), as well as food vendors (Padma and PPLM).

\subsection{FINDINGS}

\subsubsection{Coopetition among actors in the Informal Tourism Economy}

Results show that actors engage in cooperation and competition as individuals (individual level), as members of a union (a group/union level), or as a union (inter-groups level). This is in line with the organizational perspective of coopetition that hierarchically distinguishes the relationships/interactions among competitive actors (Bengtsson, Eriksson \& Wincent, 2010). The cooperation and competition activities that take place at each level of this hierarchy are outlined in Table 2.

\section{Table 2}

Cooperation and competitive situations among pedicab drivers and street vendors.

\begin{tabular}{|c|c|c|c|c|}
\hline \multirow{2}{*}{$\begin{array}{l}\text { Level of } \\
\text { Coopetition }\end{array}$} & \multicolumn{2}{|c|}{ Pedicab Drivers } & \multicolumn{2}{|c|}{ Street Vendors } \\
\hline & Cooperation & Competition & Cooperation & Competition \\
\hline Individual & $\begin{array}{l}\text { Serving } 3+\text { in a group } \\
\text { (i.e. family). }\end{array}$ & $\begin{array}{l}\text { Serving individual } \\
\text { (up to } 2 \text { ) tourist. }\end{array}$ & $\begin{array}{l}\text { - Looking after a } \\
\text { neighbour's stall } \\
\text { - } \\
\text { Serving customers } \\
\text { by providing similar }\end{array}$ & Gaining customers \\
\hline
\end{tabular}




\begin{tabular}{|c|c|c|c|c|}
\hline & & & $\begin{array}{l}\text { products } \\
\text { - Gaining customers } \\
\text { by complementing } \\
\text { products }\end{array}$ & \\
\hline $\begin{array}{l}\text { Union / } \\
\text { organization }\end{array}$ & $\begin{array}{l}\text { - Creating positive } \\
\text { ambiance } \\
\text { - Serving in-group } \\
\text { tourists } \\
\text { - Collecting union } \\
\text { money }\end{array}$ & $\begin{array}{l}\text { Serving in-group } \\
\text { tourists }\end{array}$ & $\begin{array}{l}\text { - Maintaining positive } \\
\text { ambiance } \\
\text { - Collecting union } \\
\text { money }\end{array}$ & $\begin{array}{l}\text { - Creating positive } \\
\text { ambiance in each } \\
\text { sub-union's area/ } \\
\text { space } \\
\text { - Accessing union } \\
\text { money }\end{array}$ \\
\hline Inter-group & $\begin{array}{l}\text { - Sharing place } \\
\text { - Creating positive } \\
\text { ambiance }\end{array}$ & $\begin{array}{l}\text { Gaining } \\
\text { (financial) support } \\
\text { from the formal } \\
\text { actors }\end{array}$ & $\begin{array}{l}\text { - } \text { Creating positive } \\
\text { ambiance } \\
\text { - Sharing space and } \\
\text { time }\end{array}$ & $\begin{array}{l}\text { Gaining financial } \\
\text { support from } \\
\text { national/local } \\
\text { government }\end{array}$ \\
\hline
\end{tabular}

At the individual level, pedicab drivers normally compete for customers by approaching them and offering a price. Pedicab drivers compete for the best locations to park their pedicab, they will work at popular times when there are more tourists, and use their sales skills to make a sale. However, if a group of visitors (i.e. a family group with 3 or more people) want to travel together then pedicab drivers will cooperate with other drivers since the maximum capacity of a pedicab is two passengers. Sometimes tour agencies will include a pedicab ride for a group of tourists. Here the tour agency deals with a union to organize the required number of drivers. If a pedicab driver wants to be included in the team that services this 'in tour group', they need to register their availability beforehand. Competition arises because priority is given to the first driver(s) to register - a rule imposed by the union called 'first come, first chance'. Competition will occur and the rule invoked if the number of drivers needed is those who have registered. At the individual level, street vendors sell local cuisine or souvenirs, such as handicrafts, batik, and specially designed t-shirts, and compete for customers against their co-located vendors, particularly those who sell similar products. However, vendors may cooperate by looking after a neighbour's stall for a period of time, watching the stall and even selling products if necessary. On an average day, a vendor may assist a neighbour by looking after their stall more than once, for instance, during prayer times (five times a day for a Muslim), or when the vendor has to attend an event. Street vendors also cooperate by providing a neighbouring stall-holder with an out-of- stock item to avoid them losing a customer, or by selling complementary types of 
products, thus increasing the likelihood that a customer will buy from both actors (Situation B in Fig. 4).

"Most of my customers are my neighbour's customers. She only provides water in her rice stall, so if her customers demand tea or coffee, they will order it from me (Street Vendor II-05)”.

"I provide rice, instant noodles, and tea in my stall. But if my customer(s) want to order fruit juice from my neighbour, it's okay. It's common here. Sometime, my neighbour's [selling meat-balls soup] customers buy tea from my stall (Street Vendor II-01)”.

At the union or organizational level, both pedicab drivers and street vendors cooperate by maintaining the neatness, cleanliness, and safety of their parking lots or stalls, as well as by minimizing conflicts among themselves. The main purpose of this level of cooperation is to provide a comfortable business environment for them and to attract customers (see Situation A in Fig. 3 and 4). In the case of street vendors, co-located (sub-group) vendors occasionally are engaged in neatness and cleanliness competitions such as before Indonesian Independence Day. Pedicab drivers and street vendors belong to a union which requires their members to pay a monthly membership fee. The union uses this money to provide operational costs and financial support when a member is sick or a family member dies. In the case of street vendors the operational cost includes a daily stall cleaning service. Additionally in the larger street vendor unions (more than 300 members), loans with low interest rates are available for members from a koperasi $^{1}$ (the business unit in the union). Competition may occur between members for a loan.

Inter-group cooperation occurs because there are different unions and types of businesses located in the same space. In the case of pedicab drivers, this situation occurs in the North Square of the Kraton where eight unions of pedicab drivers share this space to acquire passengers. The Square is the best place to find and acquire tourists as it provides bus and car parking for large numbers of visitors to the Kraton, and all pedicab drivers in the unions have the same rights to access these tourists. In the case of street vendors, the local government organizes the location and opening hours of each business, particularly the food vendors. These vendors sell rice and drinks, fruit salad, chicken noodles, and meatball soup during the day (0900 - 1600), while others sell traditional foods such as gudeg, and fried chicken/ quail/ duck at night (1700_

\footnotetext{
${ }^{1}$ Koperasi or cooperative is an "autonomous association of persons united voluntarily to meet their common economic, social and cultural needs and aspirations through a jointly-owned and democratically-controlled enterprise”(Smith, 2004, p. 36). In Indonesia, Koperasi is an incorporated association legalized by a notary.
} 
2400). Inter-group competition also occurs among unions of pedicab drivers and street vendors when these actors compete to gain the support of local government, formal economy stores, and management of the Kraton. Good contacts and relationships, as well as maintaining credibility by reducing conflict are essential for each union.

\subsubsection{Shared Resources during Coopetitive Behaviours}

This study found that the actors share resources as part of their coopetitive behaviours. These shared resources include customers (as potential passengers/customers) where the drivers and vendors compete individually to find and acquire customers, and cooperate with other drivers in serving the passengers/customers. Here, in the competition, if an actor succeeds in gaining tourists as passengers/ customers, it will influence other actors' opportunities to gain the same tourists. Secondly, spatial and temporal locations are also shared resources as, in the case of pedicab drivers, tourists concentrate in the Square outside the Kraton creating a shared resource. However, unions have created exclusive rights to gain passengers (related to union membership). In the case of street vendors, the street is a shared space where their stall space is allocated to them by the government. Time is also an important determinant of resource (tourist) availability as numbers vary with the opening hours of the main tourism attractions (in the case of pedicab drivers), and their allotted opening hours in the case of street vendors. The way that actors use spatial/ temporal locations influences other actors' access to these resources and impacts the coopetitive behaviours among them.

A third example of shared resources is that street vendors share union money at the intragroup level. These actors cooperate to collect union money and compete to access this money through a micro-credit system. Each union member contributes money equally, and a 'first come, first served' rule is applied in accessing it. Pedicab drivers on the other hand cooperate in collecting union money but do not compete to receive money as the union allocates the money by consensus. Finally, support from government and other formal actors enable pedicab drivers and vendors to secure their rights to work in a particular location. The actors can also use union funds to enlarge their scale of production (in the case of street vendors) or support their daily needs (pedicab drivers). Pedicab drivers obtain financial support from the government and formal stores, while street vendors have access to government schemes and money. Government 
support is selective based on the quality of submitted proposals, while formal actor support is less selective and based on the locality.

\subsubsection{The Rules in Use}

The research also identified the rules in use in each of the cooperative and competitive activities in which the pedicab drivers and street vendors are involved. In general, their activities are governed by rules related to common and group norms. Common norms are applied among the actors regardless of the location where they interact; group norms are applied only among the members of a union. Norms delineate the actors involved in the coopetition. In the case of pedicab drivers, their mobility means the rules are defined by the different locations and times where they interact. In the case of street vendors, the actors are defined by the formal regulations that allocate each vendor to a certain location and do not vary over time. For both pedicab drivers and street vendors, fairness is a basic consideration underpinning all the rules in use, such as 'first come, first chance'; 'no snatching' of others customers; 'similar profit margin/price' in deciding the product's price, and sharing costs and benefits equally among the actors based on the contribution of each in the cooperative situation.

"After serving passengers, usually, we collect the money for our service, excluding individual tips for the pedicab driver. Then, we divide the money from our service equally. Each of us will get the same amount of money [excluding tips]. (Pedicab Driver I-05)”.

"We are not allowed to prevent a customer buying goods from other vendors. It is the customer's right to choose from which vendor he/she wants to buy goods. (Street Vendor II-01)”.

\subsubsection{The Pattern of Coopetition}

The study also explored the relationships between cooperation and competition among the actors. It was found that the same actors could be involved in a number of cooperative or competitive situations in their daily work. Three types of relationships between cooperation and competition among the actors were identified: either cooperation or competition; sequential cooperation and competition; and, simultaneous cooperation and competition. 
Firstly actors in their daily economic activities can be involved in either cooperative or competitive behaviours. This is illustrated when a pedicab driver or street vendor gains individual passengers/ customers (competition); the members of pedicab drivers' union collect money and distribute it by consensus (cooperation); and the unions of pedicab drivers or street vendors try to gain support from formal actors (competition). Here actors are involved in a single action situation until they finish their activity and so not considered as 'coopetition'.

In other situations, the actors might undertake sequential cooperation and competition within a single action situation or task. For example a pedicab driver might approach a tourist, and be asked to serve the tourist's travelling party as well (i.e. more than two people which is the pedicab’s capacity). The pedicab driver will ask other drivers to help in serving this group of tourists:

"At that moment, I approached a car that had just entered the North Square for parking. I tried to make a deal with the passengers of this car; they were a family [parents with two children]. They wanted to visit the Horse Carriage Museum, Kraton, and Water Castle. Finally, after we agreed on the route and price, I asked one of my friends to join me. So, in total, two pedicab drivers served this family. (Pedicab Driver I-05)”.

Here, the pedicab driver changes from competition to cooperation. When this task is finished the actors return to competition. This situation may occur repeatedly (Situation D in Fig. 3).

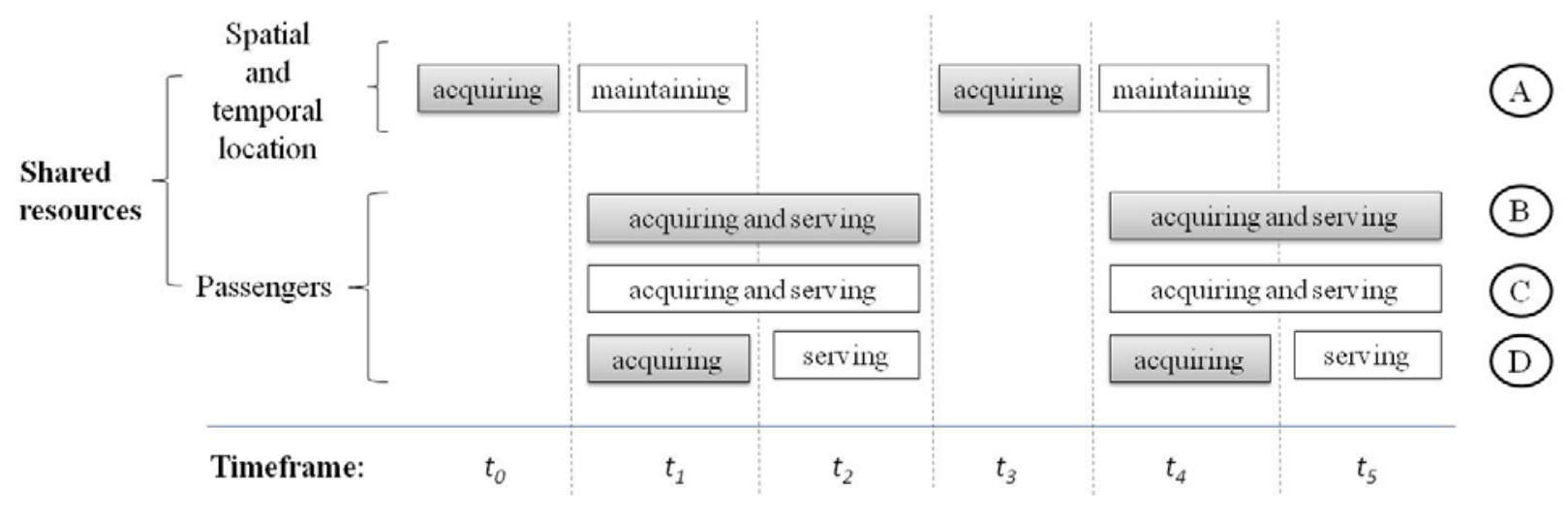

Note:

competitive cooperative

Fig. 3. The patterns of coopetition among the pedicab drivers 
Street vendors exhibit the same pattern, for example, in serving customers who want multiple products, and an individual vendor does not have all that is required by the customer. Here, two or more vendors may change from competition to cooperation then back again to competition after the customers receive the goods and the actors share the money (Situation $C$ in Fig. 4).

"If my customer wants to buy 10 pieces of batik, but I don't have enough, I will try to find it in my neighbour's stall as we sell similar goods. I just say: 'Sir, I need five pieces of batik for 40,000 rupiah [approximately AUD\$ 4.00] per piece; may I get it from you?’ (Street Vendor I-02)”.

Cooperative and competitive activities

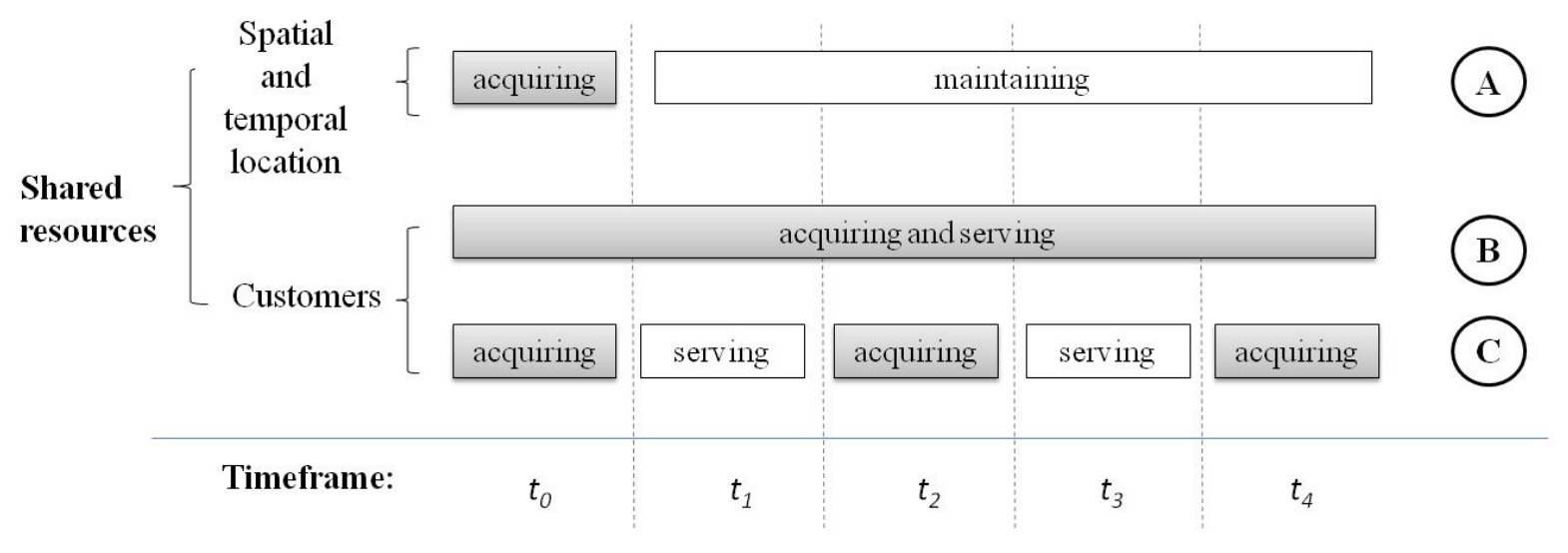

Note:

competitive

$$
\text { cooperative }
$$

Fig. 4. The patterns of coopetition among street vendors

In reality, the actors share more than one resource during their interaction. For example actors compete to gain passengers/customers while cooperating in sharing a spatial and temporal location where they need to maintain a positive ambiance (parking lots or stalls). If there is fighting for customers or the street looks untidy then all the drivers may lose customers. Here, simultaneously the actors interact in competitive (for customers) and cooperative (maintaining a tidy street) situations.

"Previously Malioboro Street was well known as being unsafe for tourists due to a quite large number of pickpockets in this area. In order to eliminate this image, we remind each vendor to be aware of these criminals. Furthermore, we have some vendors in charge of security who will catch the 
criminals. We want to create a safe environment, so more tourists will come to visit Malioboro and to buy our goods. (Street Vendor III-04)”.

Interestingly, the patterns of simultaneous coopetition between pedicab drivers and street vendors are different possibly due to differences in their product offering. Pedicab drivers utilize various parking ranks in the course of transporting passengers from one place to the others. While the pedicab drivers will interact with other drivers in the parking area, they have no obligation to maintain the positive ambiance in these parking lots. Pedicab drivers will be involved in simultaneous coopetition again with the same actors only if these actors are present again in the parking lot and seeking to acquire passengers. As illustrated in Fig. 3, the actors might be involved in the sequential situation $A+B$, or $A+C$, or $A+D$ throughout the day. On the other hand, in the case of street vendors, actors will interact and engage in simultaneous coopetition from the time they open their stall until they close it and leave the space. Therefore the street vendors might be involved in situation A + B or A + C (see Fig. 4). In terms of time (duration), the simultaneous coopetition among the street vendors is longer than that of the pedicab drivers.

\subsection{CONCLUSION}

Previously coopetition has been explored only in the formal economy (Bengtsson \& Kock, 2000; Brandenburger \& Nalebuff, 1996; Lado, Boyd \& Hanlon, 1997; Tsai, 2002). This study sought to explore patterns of coopetition in the context of the informal tourism economy. The findings were derived from case studies of pedicab drivers and street vendors in Yogyakarta, Indonesia. Research undertaken in the context of the formal economy has identified that sequential and simultaneous patterns of coopetition take place (Galvagno \& Garraffo, 2010). However, this study has used shared resources among the actors to more closely define the patterns of their coopetitive behaviours. The results indicate that cooperative and competitive situations among the same actors occur sequentially when there is a single shared resource (see Situation D in Fig. 3 and Situation C in Fig. 4), but where there are multiple shared resources (i.e. space/temporal location and customers/passengers) there may be simultaneous cooperative and competitive situations. A sequential pattern of cooperation and competition among the actors 
demonstrates that in the context of the informal economy, individual actors may quickly shift from competition to cooperation or vice versa as a response to market (demand) change depending on the transaction. If a street vendor or pedicab driver does not have the capacity to fulfil a transaction, the individual actors will move from competition to cooperation to collectively avoid losing the customer. Once, this cooperative transaction is completed the actors will return to competing for customers. Based on this phenomenon, it can be considered that the informal economy has high adaptive capacity in dealing with the changes in the market (demand) as a part of their survival strategy. Thus, this research suggests the need for further research to examine the informal economy’s adaptive capacity in dealing with other external factors, such as political or macroeconomic changes.

The research findings also have implications for actors in the formal economy. First, other studies have found formal economy actors present coopetitive patterns similar to those of street vendors (Fig. 4). Sequential coopetition (Situation C in Fig.4) was noted in value chain research (Bonel \& Rocco, 2007; Gnyawali \& Park, 2011), and in destination marketing when various actors cooperate in destination marketing and compete in gaining tourist in the destination (Belleflamme \& Neysen, 2009; Kylänen \& Rusko, 2010; von Friedrichs Grängsjö, 2003; Wang \& Krakover, 2008). However, coopetitive actors may organise to Situation A in Fig, 4. Here, competition may initially occur among actors through processes such as membership fees based on willingness to pay (Belleflamme \& Neysen, 2009) and bidding process (Werner, Dickson \& Hyde, 2015). The actors so chosen can then undertake cooperative activities such as developing an e-tourism platform (Belleflamme \& Neysen, 2009). The findings also imply that formal economy actors need flexibility to move from cooperation into competition and vice versa, when dealing with fast changes in demand. This may be a challenge for formal economy actors bound by rules in use such as inflexible contracts (Eriksson, 2008). Hence, further research exploring how formal contracts affect the adaptive capacity of formal economy actors is recommended. Further, longitudinal research designs allowing collection of more complex data is recommended.

This research has provided some of the first insights into the patterns of coopetition that exist among actors in the informal economy and in doing so has extended the concept of coopetition that has to now only been applied in a formal economy context. The use of Ostrom's IAD Framework (Ostrom, 2005b, 2011) has facilitated the examination of action situations that 
provide additional insights into social spaces and situations where/when two or more actors interact and exchange resources or compete/fight in gaining resources. Examining coopetition in terms of shared resources among actors, applied rules in use/institutions, and attributes of the actors has provided further insights into the complexity of coopetition in an informal economy context.

\section{REFERENCES}

Adams, R. D., \& McCormick, K. (1987). Private goods, club goods, and public goods as a continuum. Review of Social Economy, 45(2), 192-199.

Bah, A., \& Goodwin, H. (2003). Improving access for the informal sector to tourism in Gambia. London: ODI.

Bazeley, P., \& Richards, L. (2000). The NVivo qualitative project book. London: SAGE Publications.

Belleflamme, P., \& Neysen, N. (2009). Coopetition in infomediation: General analysis and application to e-tourism. In Á. Matias, P. Nijkamp \& M. Sarmento (Eds.), Advances in tourism economics: New developments (pp. 217-234). Heidelberg: Physica-Verlag.

Bengtsson, M., Eriksson, J., \& Wincent, J. (2010). Coopetition: New ideas for a new paradigm. In S. Yami, S. Castaldo, G. B. Dagnino \& F. L. Roy (Eds.), Coopetition: Winning strategies for the 21st century (pp. 19-39). Cheltenham: Edward Elgar Publiching Limited.

Bengtsson, M., \& Kock, S. (2000). "Coopetition" in business networks--to cooperate and compete simultaneously. Industrial Marketing Management, 29(5), 411-426.

Bengtsson, M., \& Kock, S. (2014). Coopetition-Quo vadis? Past accomplishments and future challenges. Industrial Marketing Management, 43(2), 180-188.

Bhowmik, S. K. (2005). Street vendors in Asia: A review. Economic and Political Weekly, May 28-June 4, 2256-2258.

Biernacki, P., \& Waldorf, D. (1981). Snowball sampling: Problems and techniques of chain referral sampling. Sociological Methods \& Research, 10(2), 141-163.

Bonel, E., \& Rocco, E. (2007). Coopeting to survive: Surviving coopetition. International Studies of Management \& Organization, 37(2), 70-96.

Bosch, M., \& Esteban-Pretel, J. (2012). Job creation and job destruction in the presence of informal markets. Journal of Development Economics, 98(2), 270-286.

Brandenburger, A. M., \& Nalebuff, B. J. (1995). The right game: Use game theory to shape strategy (Vol. 73). Chicago: Harvard Business Review.

Brandenburger, A. M., \& Nalebuff, B. J. (1996). Co-opetition. London: HarperCollinsBusiness.

Briassoulis, H. (1999). Sustainable development and the informal sector: An uneasy relationship? The Journal of Environment \& Development, 8(3), 213-237.

Briassoulis, H. (2001). Sustainable development - The formal and informal way? In K. Eder \& M. Kousis (Eds.), Environmental politics in Southern Europe: Actors, institutions, and discources in a Europeanizing society (pp. 73-100). Dordrecht: Kluwer Academic.

Briassoulis, H. (2002). Sustainable tourism and the question of the commons. Annals of Tourism Research, 29(4), 1065-1085.

Bromley, R. (1978). Organization, regulation and exploitation in the so-called 'urban informal sector': The street traders of Cali, Colombia. World Development, 6(9-10), 1161-1171.

Brown, A., Lyons, M., \& Dankoco, I. (2010). Street traders and the emerging spaces for urban voice and citizenship in African cities. Urban Studies, 47(3), 666-683. 
Burke, T., Genn-Bash, A., \& Haines, B. (1991). Competition in theory and practice (revised ed.). London: Routledge.

Chen, M. A. (2006). Rethinking the informal economy: Linkages with the formal economy and the formal regulatory environment. In B. Guha-Khasnobis, R. Kanbur \& E. Ostrom (Eds.), Linking the formal and informal economy - concepts and policies (pp. 75-92). New York: Oxford University Press.

Chen, M. J. (2008). Reconceptualizing the competition-cooperation relationship. Journal of Management Inquiry, 17(4), 288-304.

Clement, F. (2010). Analysing decentralised natural resource governance: proposition for a "politised" institutional analysis and development framework. Policy Sciences, 43, 129-156.

Coleman, E. A., \& Steed, B. C. (2009). Monitoring and sanctioning in the commons: An application to forestry. Ecological Economics, 68(7), 2106-2113.

Cukier, J. (2002). Tourism employment issues in developing countries: Examples from Indonesia. In R. Sharpley \& D. J. Telfer (Eds.), Tourism and development: Concepts and issues (pp. 165-201). Clevedon, New York, Toronto: Channel View Publications.

Dagnino, G. B. (2009). Coopetition strategy: A new kind of interfirm dynamics for value creation. In G. B. Dagnino \& E. Rocco (Eds.), Coopetition strategy: Theory, experiments, and cases (pp. 25-43). New York: Routledge.

Dagnino, G. B., \& Padula, G. (2002). Coopetition strategy: a new kind of interfirm dynamics for value creation. Paper presented at the European academy of management second annual conference "Innovative research in management", Stockholm.

Dahles, H., \& Bras, K. (1999). Entrepreneurs in romance: tourism in Indonesia. Annals of Tourism Research, 26(2), 267-293.

Damayanti, M., Ruhanen, L., \& Scott, N. (2011). Organic innovation in the informal tourism sector: The case of the becak wisata, Yogyakarta. Paper presented at the Council for Australian University Tourism and Hospitality Education (CAUTHE) 2011, Adelaide.

Della Corte, V., \& Aria, M. (2016). Coopetition and sustainable competitive advantage. The case of tourist destinations. Tourism Management, 54, 524-540.

Donovan, M. G. (2008). Informal cities and the contestation of public space: The case of Bogota, street vendors 1988-2003. Urban Studies, 45(1), 29-51.

Eisenhardt, K. M. (1989). Building theories from case study research. The Academy of Management Review, 14(4), 532-550.

Enz, C. A. (2010). Hospitality strategic management: Concepts and cases (2nd ed.). Hoboken: John Wiley \& Sons.

Eriksson, P. E. (2008). Achieving suitable coopetition in buyer-supplier relationships: The case of Astra Zeneca. Journal of Business-to-Business Marketing, 15(4), 425-454.

Fajana, S. (2008). The Nigerian informal economy: Instigating decent work and pay, and national development through unionisation. Employee Relations, 30(4), 372 - 390.

Galvagno, M., \& Garraffo, F. (2010). The promise of coopetition as a new theoretical perspective in strategic management In S. Yami, S. Castaldo, G. B. Dagnino \& F. L. Roy (Eds.), Coopetition: Winning strategies for the 21st century (pp. 40-57). Cheltenham: Edward Elgar Publiching Limited.

Gnyawali, D. R., \& Park, B. (2011). Co-opetition between giants: Collaboration with competitors for technological innovation. Research Policy, 40(5), 650-663.

Gomes-Casseres, B. (1996). The alliance revolution: The new shape of business rivalry. Cambridge: Harvard University Press.

Hampton, M. P. (2003). Entry points for local tourism in developing countries: Evidence from Yogyakarta, Indonesia. Geografiska Annaler. Series B, Human Geography, 85(2), 85-101.

Hart, K. (2006). Bureaucratic form and the informal economy. In B. Guha-Khasnobis, R. Kanbur \& E. Ostrom (Eds.), Linking the formal and informal economy - concepts and policies (pp. 20-35). New York: Oxford University Press. 
Heckathorn, D. D. (2002). Respondent-driven sampling II: Deriving valid population estimates from chain-referral samples of hidden populations. Social Problems, 49(1), 11-34.

ILO. (2003). Trade unions and the informal sector: Towards a comprehensive strategy. Geneva: International Labor Organization.

Kermath, B. M., \& Thomas, R. N. (1992). Spatial dynamics of resorts: Sosúa, Dominican Republic. Annals of Tourism Research, 19(2), 173-190.

Ketchen, D. J., Ireland, R. D., \& Webb, J. W. (2014). Toward a Research Agenda for the Informal Economy: A Survey of the Strategic Entrepreneurship Journal's Editorial Board. Strategic Entrepreneurship Journal, 8(1), 95-100.

Kylänen, M., \& Rusko, R. (2010). Unintentional coopetition in the service industries: The case of PyhäLuosto tourism destination in the Finnish Lapland. European Management Journal, 29(3), 193205.

Lado, A. A., Boyd, N. G., \& Hanlon, S. C. (1997). Competition, cooperation, and the search for economic rents: A syncretic model. The Academy of Management Review, 22(1), 110-141.

Luo, Y. (2004). A coopetition perspective of MNC-host government relations. Journal of International Management, 10(4), 431-451.

Lyons, M., \& Snoxell, S. (2005a). Creating urban social capital: Some evidence from informal traders in Nairobi. Urban Studies, 42(7), 1077-1097.

Lyons, M., \& Snoxell, S. (2005b). Sustainable urban livelihoods and marketplace social capital: Crisis and strategy in petty trade. Urban Studies, 42(8), 1301-1320.

Ma, H. (2004). Toward global competitive advantage: Creation, competition, cooperation, and co-option. Management Decision, 42, 907-924.

Marshall, M. N. (1996). Sampling for qualitative research. Family Practice, 13(6), 522-526.

McGinnis, M. D. (2011). An introduction to IAD and the languange of the Ostrom workshop: A simple guide to a complex framework. The Policy Studies, 39(1), 169-183.

Meagher, K. (2005). Social networks and economic ungovernance in African small firm clusters Retrieved 23 February, 2011, from http://www.qeh.ox.ac.uk/dissemination/conferencepapers/meagher.pdf

Mishra, P. K., \& Kumar, M. (2007). Institutionalising common pool resources management: Case studies of Pastureland management. Economic and Political Weekly, September, 3644-3652.

Nielsen, R. P. (1988). Cooperative strategy. Strategic Management Journal, 9(5), 475-492.

Ostrom, E. (2005a). Doing institutional analysis: Digging deeper than markets and hierarchies. In C. Menard \& M. M. Shirley (Eds.), Handbook of new institutional economics (pp. 819-848). Dordrecht: Springer.

Ostrom, E. (2005b). Understanding institutional diversity. Princeton: Princeton University Press.

Ostrom, E. (2009). Institutional rational choice: an assessment of the Institutional Analysis and Development Framework. In P. A. Sabatier (Ed.), Theories of the policy process (pp. 21-64). Boulder: Westview Press.

Ostrom, E. (2010). Beyond market and states: Polycentric governance of complex economic systems. American Economic Review, 100, 1-33.

Ostrom, E. (2011). Background on the institutional analysis and development framework. The Policy Studies, 39(1), 7-27.

Padula, G., \& Dagnino, G. B. (2007). Untangling the rise of coopetition. International Studies of Management \& Organization, 37(2), 32-52.

Palmer, A. (2000). Co-operation and competition: a Darwinian synthesis of relationship marketing. European Journal of Marketing, 34(5/6), 687 - 704.

Peña, S. (1999). Informal markets: Street vendors in Mexico City. Habitat International, 23(3), 363-372.

Putri, A. (2009). Street vendor behaviours in tourism marketing: case of Malioboro, Yogyakarta. (BSc Thesis), Diponegoro University, Semarang.

Rakodi, C., \& Lloyd-Jones, T. (Eds.). (2002). Urban livelihoods: A people-centred approach to reducing poverty. London: Earthscan. 
Richards, L. (1999). Unsing NVivo in qualitative research. London: SAGE Publications.

Sandler, T., \& Tschirhart, J. (1997). Club theory: Thirty years later. Public Choice, 93, 335-355.

Sethuraman, S. V. (1976). The urban informal sector: Concept, measurement and policy. International Labour Review, 114(1), 69-81.

Slocum, S. L., Backman, K. F., \& Robinson, K. L. (2011). Tourism pathways to prosperity: Perspectives on the informal economy in Tanzania. Tourism Analysis, 16(1), 43-55.

Smith, R. A., \& Henderson, J. C. (2008). Integrated beach resorts, informal tourism commerce and the 2004 tsunami: Laguna Phuket in Thailand. International Journal of Tourism Research, 10(3), 271282.

Smith, S. (2004). Promoting co-operatives: a guide to ILO recommendation 193. Manchester: the Cooperative College

Teece, D. J. (1992). Competition, cooperation, and innovation: Organizational arrangements for regimes of rapid technological progress. Journal of Economic Behavior \& Organization, 18(1), 1-25.

Timothy, D. J., \& Wall, G. (1997). Selling to tourists - Indonesian street vendors. Annals of Tourism Research, 24, 322-340.

Todaro, M. P., \& Smith, S. C. (2012). Economic development (11th ed.). Boston: Addison Wesley.

Torfing, E. S. J. (2006). Theories of democratic network governance. Basingstoke: Palgrave Macmillan.

Tsai, W. (2002). Social structure of "coopetition" within a multiunit organization: Coordination, competition, and intraorganizational knowledge sharing. Organization Science, 13(2), 179-190.

Uriely, N., \& Belhassen, Y. (2006). Drugs and risk-taking in tourism. Annals of Tourism Research, 33(2), 339-359.

van Gemert, H., van Genugten, E., \& Dahles, H. (1999). Tukang becak: The pedicab men of Yogyakarta. In H. Dahles \& K. Bras (Eds.), Tourism and small entrepeneurs: Development, national policy, and entrepreneurial culture: Indonesian cases (pp. 97-111). New York: Cognizant Communication Corporation.

Varcin, R. (2000). Competition in the informal sector of the economy: the case of market traders in Turkey. International Journal of Sociology and Social Policy, 20(3/4), 5 - 33.

von Friedrichs Grängsjö, Y. (2003). Destination networking: Co-opetition in peripheral surroundings. International Journal of Physical Distribution \& Logistics Management, 33(5), 427-448.

Walley, K. (2007). Coopetition: An introduction to the subject and an agenda for research. International Studies of Management \& Organization, 37(2), 11-31.

Wang, Y., \& Krakover, S. (2008). Destination marketing: Competition, cooperation or coopetition? International Journal of Contemporary Hospitality Management, 20(2), 126-141.

Werner, K., Dickson, G., \& Hyde, K. F. (2015). Coopetition and Knowledge Transfer Dynamics: New Zealand's Regional Tourism Organizations and the 2011 Rugby World Cup. Event Management, 19(3), 365-380.

Widiyanto, D. (2013, March 3). Pemkot sulit pastikan kapasitas PKL Malioboro [The local government has challanged to define the capacity of Malioboro Street for the street vendors], Kedaulatan Rakyat. Retrieved from http://krjogja.com/read/167333/pemkot-sulit-pastikan-kapasitas-pklmalioboro.kr

Wilkinson, I., \& Young, L. (2002). On cooperating: Firms, relations and networks. Journal of Business Research, 55(2), 123-132.

Yeo, S. J., \& Heng, C. K. (2014). An (Extra)ordinary Night Out: Urban Informality, Social Sustainability and the Night-time Economy. Urban Studies, 51(4), 712-726.

Yin, R. K. (2009). Case study research: Design and methods (4th ed.). Thousand Oaks: SAGE Publications. 